\title{
Immunomodulatory effects of phytogenics in chickens and pigs A review
}

\author{
C. M. Huang ${ }^{1}$ and T. T. Lee ${ }^{1,2, *}$
}

* Corresponding Author: T. T. Lee Tel: +886-4-2287-0613, Fax: +886-4-2286-0265,

E-mail: ttlee@dragon.nchu.edu.tw

${ }^{1}$ Department of Animal Science, National Chung Hsing University, Taichung 402, Taiwan

${ }^{2}$ The iEGG and Animal Biotechnology Center, National Chung Hsing University, Taichung 402, Taiwan

ORCID

C. M. Huang

https://orcid.org/0000-0001-7692-5542

T. T. Lee

https://orcid.org/0000-0002-0063-5714

Submitted Sept 4, 2017; Revised Oct 17, 2017; Accepted Nov 17, 2017

\begin{abstract}
Environmental stressors like pathogens and toxins may depress the animal immune system through invasion of the gastrointestinal tract (GIT) tract, where they may impair performance and production, as well as lead to increased mortality rates. Therefore, protection of the GIT tract and improving animal health are top priorities in animal production. Being natural-sourced materials, phytochemicals are potential feed additives possessing multiple functions, including: anti-inflammatory, anti-fungal, anti-viral and antioxidative properties. This paper focuses on immunity-related physiological parameters regulated by phytochemicals, such as carvacrol, cinnamaldehyde, curcumin, and thymol; many studies have proven that these phytochemicals can improve animal performance and production. On the molecular level, the impact of inflammatory gene expression on underlying mechanisms was also examined, as were the effects of environmental stimuli and phytochemicals in initiating nuclear factor kappa B and mitogen-activated protein kinases signaling pathways and improving health conditions.
\end{abstract}

Keywords: Phytogenics; Phytochemicals; Immune Response; Inflammatory Cytokines; Domestic Animals

\section{INTRODUCTION}

Pathogens like viruses, bacteria, fungi and other environmental stimuli are latent stressors which may damage animal tissues and cells. Excessive stressors may increase the concentration of reactive oxygen species (ROS), causing lipid peroxidation and oxidative damage to cellular membranes. The lack of sufficient antioxidants to eliminate ROS will lead to oxidative damage and trigger inflammation [1-3]. When inflammation occurs, cells have to recruit other cells to local sites by secreting more inflammatory cytokines and chemokines; this is a necessary process for the host to fight against infection and to repair tissue. However, prolonged inflammation may lead to unnecessary energy expenditure. As such, the alleviation and prevention of over-inflammation and the return of immune status to normal condition will benefit animal production.

As the first line of defense, the gastrointestinal tract (GIT) has a large surface area where food degradation and absorption take place; pathogens and toxins may also gain access to the body through the GIT by destroying the mucus layer [4]. Accordingly, protection of the GIT against the incursion of pathogens and toxins is of vital importance. Common toxins, such as aflatoxin and lipopolysaccharide (LPS), may cause great damage to intestinal cells, induce inflammation and immune response, and impair production $[5,6]$. Toxic airborne gases, like ammonia, may harm the respiratory system of animals, resulting in depressed performance $[7,8]$. Exogenous stressors may exacerbate the pathogenic invasion in the gut of animals, indicated by decreased bodyweight and feed intake, infiltration of heterophils in 
the intestine and increased Salmonella numbers in the spleens of heat stressed chickens after Salmonella infection [9]. Coccidiosis, a parasitic disease in birds infected mainly with Eimeria spp., is a major problem in the poultry industries worldwide, resulting in enormous annual losses [10]. These stressors impair mucosal immune responses to other pathogens and cause intestinal damage and poor growth performance $[6,11]$. Therefore, many different feed additives, like antibiotics, probiotics, prebiotics and phytogenics, have been added to animal diets to improve the hosts' capacity to eliminate the negative influence of environmental stressors and improve growth performance [12-17].

Antibiotics had been widely used in the livestock industry, but adverse effects, including drug resistance and reduced beneficial endogenous bacteria counts, led to subsequent prohibition against antibiotic supplementation by the European Union in 2006. Many other governments also began to restrict antibiotic supplementation, prompting a great deal of new research into phytochemicals as alternative feed additives. It was observed that supplementation of phytochemicals had positive effects on the pancreatic and intestinal enzyme secretion in broilers $[18,19]$, and improved dry matter and crude protein digestibility in pigs [20]. Although inconsistent results of feed intake suggested that phytogenics might not improve feed palatability, feeding phytogenics did promote nutrient absorption and feed conversion ratio (FCR) in poultry [21]. Many authors have pointed out that phytogenics in animal diet improved the immune response and the protective capacity of the GIT against exogenous stressors [22-26]; however, the mechanisms by which phytochemicals act on host cells were still unclear. In this review, we summarize the known relevant mechanisms in mammals and poultry, and suggest the potential immunomodulatory effects of phytochemicals on chickens and pigs.

\section{EFFECTS OF PHYTOCHMICALS ON IMMUNE RESPONSE}

Phytochemicals, the active constituents in phytogenics, can be roughly divided into two groups based on the different synthetic pathways in plants: terpenes and terpenoids, or aromatic and aliphatic compounds [27]. Some phenolic compounds and terpenes have been reported to exhibit anti-inflammatory activity $[28,29]$. However, as all the phytochemicals were extracted under different conditions or by using different parts of the plant, it is difficult to evaluate their effect. Phytogenics have traditionally been used in powder form, but antagonizing or additive reactions between compounds in a single phytogenic may result, as inconsistent results of immunoregulatory action between treatments of phytogenic and its individual component were found $[30,31]$. It's difficult to study the possible interactions between compounds in phytogenics, not to mention the diversity of phytogenics and phytochemicals. As such, the complexity of the immunoregulatory actions of phytogenics limits the progress of related research. Nevertheless, phytogenics and phytochemicals still remain among the most promising feed additives thanks to their positive effect on regulating the immune response in chickens and pigs. Here we review the effects of some popularly applied phytogenics on the immune response in animals, including Echinacea purpurea L. (EP), oregano, cinnamon, Curcuma longa, and thyme (Table 1).

\section{Echinacea purpurea L.}

In our previous studies, EP extract, the herbal medicine normally used to prevent respiratory infections in humans, was evaluated for its antioxidant activity in broilers [32-35]. The results demonstrated that EP ethanol extracts had no major influence on the viability of the mononuclear cells in peripheral blood [32]. Dietary supplementation with dried EP improved both the FCR and meat quality $[33,34]$. It was also reported that $5.0 \mathrm{~g} / \mathrm{kg}$ EP supplementation in broilers could increase the antibody titer against sheep red blood cells (SRBCs) and Newcastle disease virus (NDV) [35]. The EP, which was fed to laying hens and fattening pigs as pressed juice preserved with ethanol, still showed immunomodulatory effects, as indicated by the increased count of lymphocytes and NDV antibodies in the blood [36]. The $0.1 \%$ supplementation of EP aqueous extract in the diet enhanced cutaneous basophil hypersensitivity and antibody response against SRBCs in broilers [37]. However, no significant differences were observed in sows fed $1.2 \%$ and $3.6 \%$ EP cobs during gestation, in sows fed $0.5 \%$ and $1.5 \%$ cobs during lactation, or in piglets fed $1.8 \%$ cobs compared to the control group, while the FCR and erysipelas antibodies were improved in grower-finisher pigs supplemented with $1.5 \%$ cobs or 4 to $6 \mathrm{~mL}$ pressed juice per day [38]. Accordingly, EP supplementation may promote host immunity in broilers and fattening pigs, but determining its immunomodulatory effect and effective dosage in sows and piglets needs more research.

\section{Oregano}

Oregano belongs to the Labiatae family. Oregano is the popular name for a variety of widely distributed plant species, including Origanum vulgare L. and O. onites L., and is characterized as containing great amounts of carvacrol as the main source of its fragrance. Another plant called oregano is Coridothymus capitatus (L.) Reichenb. fil. (Spanish oregano) [39]; it has been widely studied as a feed additive in animals. MohitiAsli and Ghanaatparast-Rashti [40] reported that dietary supplementation with $300 \mathrm{ppm}$ of oregano essential oil (OEO) improved the European production efficiency factor in broilers, which was calculated according to body weight, livability, FCR and trial duration; 500 ppm OEO had no positive effect, while 
Table 1. Effect of five phytogenics, Echinacea purpurea L., oregano, cinnamon, turmeric, and thyme, on the immune responses of chickens and pigs

\begin{tabular}{|c|c|c|c|c|c|c|c|}
\hline $\begin{array}{l}\text { Phytogenic } \\
\text { materials }\end{array}$ & $\begin{array}{l}\text { Species of } \\
\text { experimental } \\
\text { animals }\end{array}$ & $\begin{array}{l}\text { Supplemented } \\
\text { form }\end{array}$ & Effective dosages & Bioactive components & $\begin{array}{l}\text { Enhanced } \\
\text { performance/ } \\
\text { production }\end{array}$ & Immune responses & References \\
\hline \multirow[t]{4}{*}{ Echinacea purpurea L. } & Broilers & Aerial part powder & 5 and $10 \mathrm{~g} / \mathrm{kg}$ diet & & $A W G, F I$, and FCR & $\begin{array}{l}\text { Higher antibody titers against } \\
\text { SRBC and NDV }\end{array}$ & Landy et al [35] \\
\hline & $\begin{array}{l}\text { Laying hens and } \\
\text { pigs }\end{array}$ & Pressed juice & $0.25 \mathrm{~mL} / \mathrm{kg} \mathrm{BW} W^{0.75}$ & & No effect & $\begin{array}{l}\text { Higher count of lymphocytes } \\
\text { and NDV antibodies in the } \\
\text { blood }\end{array}$ & Böhmer et al [36] \\
\hline & Broilers & Aqueous extract & $1 \mathrm{~mL} / \mathrm{L}$ drinking water & & No effect & $\begin{array}{l}\text { Higher antibody titer against } \\
\text { SRBC }\end{array}$ & Rahimi et al [37] \\
\hline & $\begin{array}{l}\text { Grower/finishing } \\
\text { pigs }\end{array}$ & Cobs or pressed juice & $\begin{array}{l}1.5 \% \text { cobs in the diet or } 4-6 \\
\mathrm{~mL} \text { juice per day }\end{array}$ & & FCR & Higher erysipelas antibody & Maass [38] \\
\hline \multirow[t]{4}{*}{ Oregano } & Broilers & Essential oil & $300 \mathrm{ppm}$ in the diet & & AWG and $\mathrm{Fl}$ & $\begin{array}{l}\text { Higher secondary antibody } \\
\text { titer and IgG titer, lowered H/L } \\
\text { ratio }\end{array}$ & $\begin{array}{l}\text { Mohiti-Asli and Ghanaat- } \\
\text { parast-Rashti [40] }\end{array}$ \\
\hline & Broilers & Essential oil & $\begin{array}{l}50 \text { and } 100 \mathrm{ppm} \text { in drinking } \\
\text { water }\end{array}$ & Carvacrol and thymol & BW & $\begin{array}{l}\text { Higher antibody titer against } \\
\text { NDV and avian influenza virus }\end{array}$ & Galal et al [41] \\
\hline & Sows & Essential oil & $250 \mathrm{ppm}$ in the diet & Carvacrol and thymol & Energy intake & Higher thymus Iymphocytes & Ariza-Nieto et al [43] \\
\hline & Broilers & Essential oil & $60-200 \mathrm{ppm}$ in the diet & Carvacrol and thymol & AWG and FCR & $\begin{array}{l}\text { Higher total antibody and lgG } \\
\text { antibody, lowered H/L ratio }\end{array}$ & Hashemipour et al [44] \\
\hline \multirow[t]{3}{*}{ Cinnamon } & Broilers & Powder & 4 and $8 \mathrm{~g} / \mathrm{kg}$ in the diet & & FCR & Higher lymphocytes proportion & Najafi and Taherpour [51] \\
\hline & Broilers & Oil extract & $\begin{array}{l}100 \text { and } 200 \mathrm{ppm} \text { in the } \\
\text { diet }\end{array}$ & & $W G, F l$, and FCR & $\begin{array}{l}\text { Lowered H/L ratio, higher } \\
\text { white blood cells }\end{array}$ & Al-Kassie [52] \\
\hline & Broilers & Powder & $5 \mathrm{~g} / \mathrm{L}$ in the drinking water & & Negative effect on BW & $\begin{array}{l}\text { Higher antibody titer against } \\
\text { NDV }\end{array}$ & Sadeghi et al [53] \\
\hline \multirow[t]{3}{*}{$\begin{array}{l}\text { Turmeric } \\
\text { (Curcuma longa) }\end{array}$} & Broilers & Rhizome powder & $2.5,5$, and $7.5 \mathrm{~g} / \mathrm{kg}$ diet & & Not detected & $\begin{array}{l}\text { Higher IgA, IgG, and IgM } \\
\text { levels, and decreased ratio of } \\
\text { monocytes }\end{array}$ & $\begin{array}{l}\text { Emadi and Kermanshahi } \\
\qquad \text { [55] }\end{array}$ \\
\hline & Broilers & Rhizome powder & $2 \mathrm{~g} / \mathrm{kg}$ diet & & AWG and FCR & $\begin{array}{l}\text { Higher total secondary anti- } \\
\text { body titer, and decreased H/L } \\
\text { ratio }\end{array}$ & $\begin{array}{l}\text { Akhavan-Salamat and } \\
\text { Ghasemi [56] }\end{array}$ \\
\hline & Broilers & Dried rhizome extract & $35 \mathrm{mg} / \mathrm{kg}$ diet & & BW & $\begin{array}{l}\text { Higher antibody level against } \\
\text { Eimeria microneme protein }\end{array}$ & Kim et al [23] \\
\hline \multirow[t]{4}{*}{ Thyme } & Broilers & Oil extract & $\begin{array}{l}100 \text { and } 200 \mathrm{ppm} \text { in the } \\
\text { diet }\end{array}$ & & AWG, Fl, and FCR & $\begin{array}{l}\text { Lowered H/L ratio, higher } \\
\text { white blood cells }\end{array}$ & Al-Kassie [52] \\
\hline & Broilers & Essential oil & $0.1 \%$ in the deit & & Not detected & $\begin{array}{l}\text { Higher white blood cells and } \\
\text { decreased H/L ratio }\end{array}$ & Khaksar et al [60] \\
\hline & Broilers & Essential oil & $0.02 \%$ in the diet & & FCR & Higher primary antibody titer & Najafi and Torki [64] \\
\hline & Broilers & Powder & 2,5 , and $8 \mathrm{~g} / \mathrm{kg}$ diet & $\begin{array}{l}\text { Essential oils: thymol, } \gamma \text {-terpinene, P-cy- } \\
\text { mene, carvacrol } \\
\text { Phenolic acids: salicylic acid, ellagic acid, } \\
\text { benzoic acid, chlorogenic acid, caffeic acid, } \\
\text { gallic acid, vanillic acid, cinnamic acid } \\
\text { Flavonoids: peridin, rosmarinic, quercitrin, } \\
\text { narerigin, rutin, quercetin, narenginin, } \\
\text { kaempferol, epicatechin, luteolin }\end{array}$ & $\mathrm{BW}, \mathrm{AWG}$, and $\mathrm{Fl}$ & $\begin{array}{l}\text { Higher levels of lymphocytes, } \\
\text { white blood cells, and lgG }\end{array}$ & Hassan and Awad [119] \\
\hline
\end{tabular}

BW, body weight; AWG, average weight gain; Fl, feed intake; FCR, feed conversion ratio; SRBC, sheep red blood cell; NDV, Newcastle disease virus; Ig, immunoglobulin; H/L ratio, heterophil to lymphocyte ratio.

$300 \mathrm{ppm}$ OEO in the diet produced higher secondary total antibody titer against SRBCs; in addition, the immunoglobulin $\mathrm{G}(\mathrm{IgG})$ titer was higher than it was in the control group. Another study reported that higher doses (500 and 1,000 ppm) of OEO supplementation led to positive immune responses in NDV- and avian influenza-vaccinated broilers [41]. Serum heterophil counts and the heterophil to lymphocyte ratio $(\mathrm{H} / \mathrm{L}$ ratio), both considered stress indicators [42], were decreased in birds fed 300 ppm OEO. On day 14 of lactation, higher thymus lymphocyte concentrations were observed in sows' milk after $250 \mathrm{ppm}$ OEO was added to their diet, indicating the immunostimulatory effect of OEO [43]. Other studies also reported that $300 \mathrm{ppm}$ OEO or $300 \mathrm{ppm}$ of a mixture of carvacrol and thymol could improve the growth performance or the immune response, as indicated by lowered excreta oocyst counts of coccidia [24], and increased hypersensitivity response, total antibody titer, and H/L ratio [44]. However, the growth promoting effects of OEO were inconsistent [45], probably because the immunomodulatory actions of OEO could not improve growth performance in a less harsh experimental environment when compared to practical rearing conditions.

\section{Cinnamon}

The essential oils from some Cinnamomum species contain 
great amounts of trans-cinnamaldehyde (C. burmannii), while other species do not (C. tamala, C. pauciflorum, and C. zeylanicum) [46,47]. Dietary supplementation with cinnamon leaves or extracted oil have been demonstrated to improve growth performance in broilers $[48,49]$, and decrease coliform bacteria in the jejunum and large intestine [50]. Najafi and Taherpour [51] reported that the inclusion of $0.4 \%$ and $0.8 \%$ cinnamon in broiler diets improved the FCR and increased the concentration of hemoglobin and the proportion of lymphocytes in the blood. Dosages of 100 and 200 ppm essential cinnamon oil improved FCR and body weight gain from 1 to 6 weeks, reduced the $\mathrm{H} / \mathrm{L}$ ratio and increased the level of white blood cells in broilers [52]. Conversely, positively modulated immune responses and impaired growth performance were detected in 21-day-old broilers that were given $5.0 \mathrm{~g} / \mathrm{L}$ cinnamon in their drinking water [53]. This discrepancy may be because the majority of studies supplied cinnamon to animals via their diet versus their drinking water. Furthermore, the variety of species used in the different experiments make it difficult to determine the effective dosage of cinnamon or cinnamon oil, or to make valid comparisons across studies, especially if the content of the major bioactive compounds was not measured.

\section{Turmeric (Curcuma longa)}

There are many species in the genus Curcuma, among which C. longa (turmeric) is the most studied. The major phytochemicals in the rhizome of $C$. longa vary dramatically with the environment and location. Li et al [54] concluded that curcumin, demethoxycurcumin and bisdemethoxycurcumin are the main compounds in the rhizomes, powders and extract products, whereas the concentrations of ar-turmerone, $\alpha$-turmerone, and $\beta$-turmerone are related to the quality of the turmeric oils and oleoresin products. Most studies evaluated this phytogenic in the form of turmeric rhizome powder (TRP). TRP inclusion in the diet significantly increased blood IgA, IgG, and IgM levels, and decreased the ratio of monocytes in 42-day-old broilers challenged with SRBCs [55]. Similarly, $0.2 \%$ TRP supplementation decreased the $\mathrm{H} / \mathrm{L}$ ratio and increased the total secondary antibody titer against SRBCs in broilers undergoing heat stress treatment [56]. Moreover, the addition of $0.33 \%$ and $1.0 \%$ TRP, which contained $1.16 \%$ curcumin, improved the FCR in broilers during the entire feeding period [57]. Inclusions of $0.33 \%, 0.66 \%$, and $1.0 \%$ TRP significantly reduced abdominal fat content and serum triglyceride concentration [57]. Therefore, dietary curcumin could regulate immune responses in animals; it has the potential to enhance growth performance.

\section{Thyme}

Thyme is the popular name for Thymus spp:; thymol, carvacrol, p-cymene and $\gamma$-terpinene are the major active components in the essential oil $[58,59]$. Dietary supplementation of thyme was in the form of essential oil or leaf powder. It has been shown that supplementation with thyme essential oil improved cutaneous basophil hypersensitivity to phytohaemagglutinin- $\mathrm{P}$ (PHA-P) and reduced the $\mathrm{H} / \mathrm{L}$ ratio. It also produced a more balanced intestinal microbiology, as indicated by higher Lactobacillus and Bifidobacterium counts and lower Escherichia coli (E. coli) levels in the ileum [60]. Previous studies suggested that heat stress may impair the cell-mediated immune response to PHA-P in chicks [61], highlighting the benefit of feeding thyme essential oil to birds. The $\mathrm{H} / \mathrm{L}$ ratio is a stress indicator, as mentioned above. A reduced $\mathrm{H} / \mathrm{L}$ ratio demonstrates the enhanced immunoregulatory capacity of the host. Intestinal microbiota plays an important role in the immune system of chickens [62]. Environmental stressors may change the intestinal microbiota and increase the susceptibility to colonization by pathogens in the intestine [63]. It was also reported that thyme essential oil improved bodyweight gain and FCR in broilers [52,64]. As such, thyme has potential as a feed additive in poultry production.

\section{INTERACTIONS BETWEEN PHYTOCHEMICALS AND THE MAPK- AND NFKB-REGULATED PATHWAYS IN CHICKENS AND PIGS}

\section{NFKB and MAPKs in immune responses}

Innate immunity, also known as non-specific immunity, includes activation and the recruitment of innate leukocytes like macrophages, thereby enhancing phagocytosis. As pathogens invade, innate leukocytes identify and engulf them while expressing cytokines, thereby initiating the immune response and leading to an inflammatory reaction [65]. Adaptive immunity is a specific immune system process initiated by the presentation of antigens. Pathogens and exogenous stimuli are identified and eliminated by $\mathrm{B}$ cells and T cells. Among these, helper $\mathrm{T}$ cells are induced by effector cytokines to differentiate into cell types Th1 or Th2, and subsequently deliver signals to macrophages or B cells, respectively [66]. Therefore, homeostasis is maintained through the mutual actions of the innate and adaptive immune systems.

In the innate immune system, toll-like receptors (TLRs) are the most studied pattern-recognition receptors in poultry and livestock [67-69]. As TLRs are stimulated, many signaling pathways are activated simultaneously through adaptor proteins such as myeloid differentiation primary response 88 (MyD88) and toll-IL-1-resistance domain-containing adaptor, inducing interferon $\beta$ [70]. The Src kinase plays a vital role in the activation of mitogen-activated protein kinases (MAPKs) and nuclear factor kappa $\mathrm{B}(\mathrm{NFkB})$, the two major pathways that modulate immune responses [71-73]. MAPKs are a group of protein kinases that regulate cellular activities. Among 
MAPKs, p38 protein kinase, extracellular signal-regulated protein kinase (ERK1/2), and c-Jun N-terminal kinase have been reported to be associated with the regulation of inflammation and immunity in response to environmental stress [74-76]. The NFkB-mediated pathway involves many physical reactions and is extremely important in the modulation of immunity, inflammation and apoptosis [71]. It is well known that $\mathrm{NFKB}$ is a dimer consisting of different subunits [71]. Under normal physical conditions, the dimer binds to the inhibitor of kappa B ( $\mathrm{K} \kappa \mathrm{B})$ and presents as an inactive form in the cytosol. When the cell is activated by exogenous stimuli, NFkB is liberated from its IkB-inhibited form. The inhibitor of kappa B kinase (IKK) phosphorylates the linked IкB, leading to the ubiquitination of phosphorylated IкB, and the subsequent identification and degradation by the $26 \mathrm{~S}$ proteasome [77]. Disconnected NFKB enters the nucleus, binding to a specific region of DNA, and promotes the expression of downstream genes. Translated proteins are secreted into the extracellular space to modulate the immune system and inflammatory response [78]. Depending on the strength, timing and site of stimulation, different downstream products are generated and exert diverse functions, including cellular growth, differentiation, tissue repair and synthesis of tissue collagen. Therefore, studies on NFkB signaling include its onset and therapies for many diseases as well as the apoptosis of cancer cells [79]. Pro-inflammatory cytokines, ROS and mitogens generated by bacterial or viral infection, chemical and biological tissue damage or other stressors, induce the activation of NFKB signaling [80,81], followed by the expression of more inflammatory cytokines and chemokines. Interleukin 1 (IL-1), IL-6, and tumor necrosis factor alpha (TNF- $\alpha$ ) are the three most investigated pro-inflammatory cytokines that can be expressed by monocytes and macrophages after invading pathogens are identified. These cytokines mediate metabolic changes, which enhance the immune response and disease resistance, thereby stunting growth performance $[82,83]$. TNF- $\alpha$ may be secreted by activated macrophages and lead to chemotaxis of monocytes [84]. Expressions of IL-1 $\beta$, IL-6 and TNF- $\alpha$ are highly associated with the immune status of poultry and livestock [85].

Nitric oxide (NO) and prostaglandin $\mathrm{E}_{2}$ (PGE2) are important inflammatory mediators that modulate the development of inflammation [86,87]. After NFkB is activated, NFkB-mediated signaling molecules upregulate the expression of the downstream gene $C O X-2$, synthesizing cyclooxygenase 2 , which converts arachidonic acid into PGE2. Inducible nitric oxide synthase (iNOS) is also activated, which subsequently increases NO production [88]. The enhanced production of histamine and PGE2 in response to stressors not only induces phagocytosis of macrophages, but also affects the production of cytokines by $\mathrm{T}$ cells, macrophages and dendritic cells $[87,89]$. These cytokines include IL-1 and IL-6, which are transported through the circulatory system to the brain, activating the hypothalamic-pituitary-adrenal (HPA) axis [90]. In response to acute inflammation, the HPA axis is stimulated to secrete more glucocorticoids, which have been thought to elevate the $\mathrm{H} / \mathrm{L}$ ratio in birds and the neutrophil to lymphocyte ratio in mammals. Glucocorticoids also induce heterophils (neutrophils) to express pro-inflammatory cytokines, including IL-1 $\beta$, IL-6, IL-10, IL-12 $\alpha$, and IL-18 [91]. Increased heterophils (neutrophils) and decreased lymphocytes in the circulatory system represent the development of the innate response in the host as inflammation is triggered. Elevated $\mathrm{H} / \mathrm{L}$ ratio is considered a stress marker. Exogenous substances are eliminated through acute inflammation in organisms. However, under stressful conditions, the suppressed immune system is unable to cope, leading to chronic inflammation [92]. It has been proven that chronic inflammation is associated with bacterial disease and heat stress in animals $[9,93,94]$. In the previous section, we reviewed that phytogenics, such as oregano, cinnamon, turmeric, and thyme, are able to modulate humoral responses in chickens and pigs. Their major components have been reported to regulate NFKB and/or MAPKs signaling pathways in rodents [95-97]. Therefore, phytochemicals that modulate the immune response and regulate the expression of inflammatory mediators in chickens and pigs were introduced (Figure 1); they are listed below.

\section{Carvacrol}

Carvacrol (2-methyl-5-(1-methylethyl)-phenol), the major active component in oregano and thyme essential oils, is a phenolic monoterpene. In mice, carvacrol reduced local levels of IL- $1 \beta$ and PGE2, and mRNA levels of COX-2 and IL- $1 \beta$ [98]. The mRNA and protein levels of TNF- $\alpha$, IL-6, Inos, and COX-2 were also downregulated in D-galactosamine-induced hepatotoxic rats after treatment with carvacrol. The suppression of pro-inflammatory cytokine production may be attributed to the inhibition of TLR2- and TLR4-mediated signaling [99]. Zou et al [100] reported that OEO, which contains 81.92\% carvacrol, lowered the protein level of MAPKs and NFkB, and decreased the expression of the pro-inflammatory cytokines IL-1 $\beta$, IL-6, interferon- $\gamma$ (IFN- $\gamma$ ), TNF- $\alpha$ and monocyte chemotactic protein-1 in the jejuna of pigs, proving its antiinflammatory effects. Moreover, the mRNA levels of occludin and zonula occludens-1, two epithelial tight junction proteins, were increased, demonstrating that carvacrol may improve the integrity of intestinal epithelia. Reduced expression of IL-6 and LPS-induced TNF- $\alpha$ factor were observed in Eimeria oocyst-challenged broilers supplemented with essential oils containing $81.89 \%$ carvacrol [101]. It is speculated that carvacrol may suppress TLRs and/or MAPKs and NFkB signaling pathways in animals; however, more studies are needed to elucidate its mechanisms in detail. 


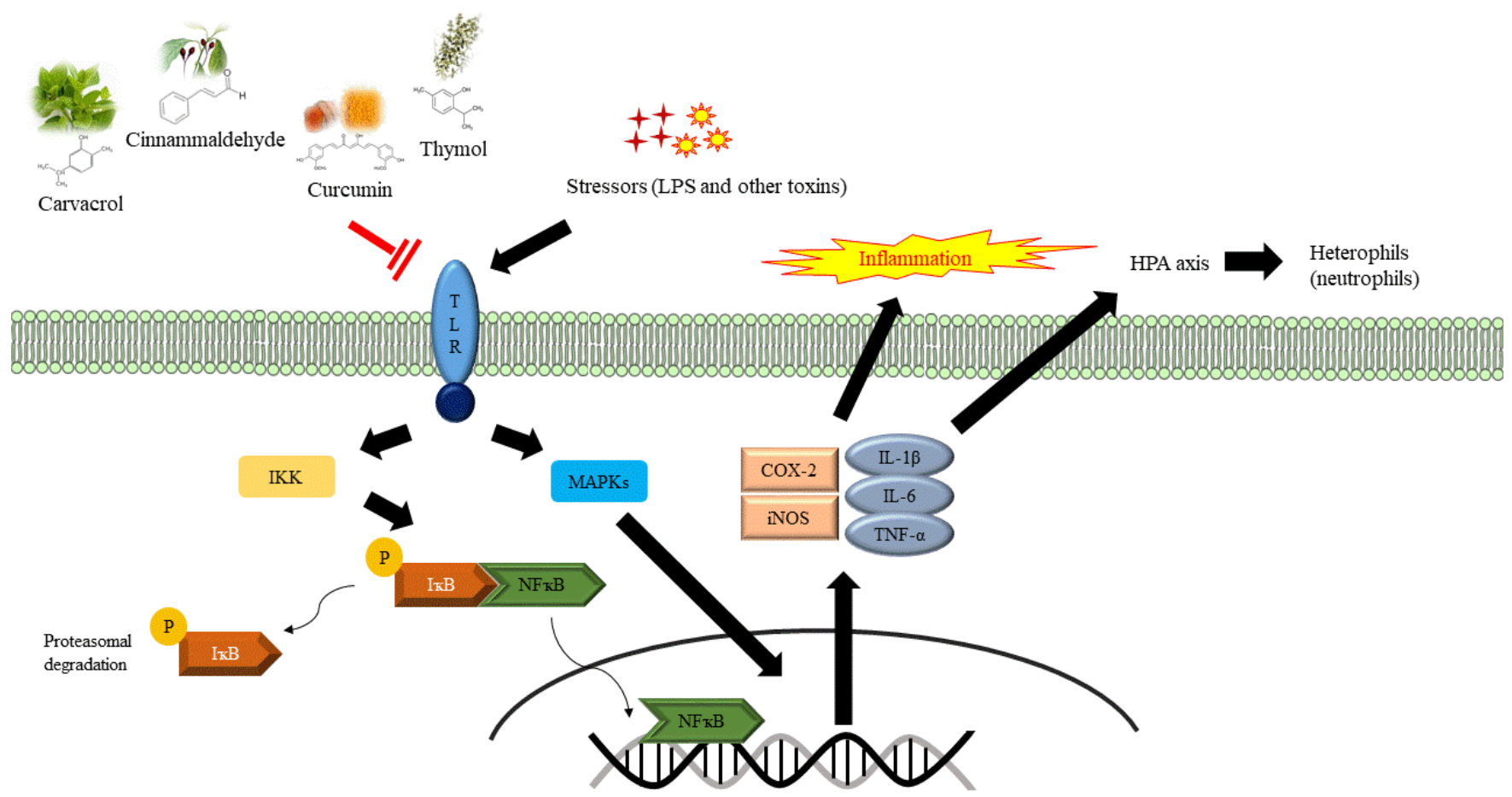

Figure 1. The possible immunomodulatory action of carvacrol, cinnamaldehyde, curcumin, and thymol regulating expression of pro-inflammatory mediators and enzymes involved in the nuclear factor kappa B (NFkB) and mitogen-activated protein kinases (MAPKs) signaling pathways, inflammation, and immune response in chickens and pigs.

\section{Cinnamaldehyde}

In vitro studies have demonstrated that both Cinnamomum cassia oil and cinnamaldehyde, the major bioactive compound in cinnamon, inhibited mRNA expression of pro-inflammatory cytokines, including IL- $1 \beta$, IL- 6 , and TNF- $\alpha$, and increased the production of anti-inflammatory cytokine IL-10 in LPSactivated J774A.1 cells. Subsequently, the expression of iNOS and COX-2 was decreased, as was NO production [102]. Youn et al [95] reported that cinnamaldehyde could suppress LPSinduced activation of $\mathrm{NF \kappa B}$ and interferon regulatory factor 3 , resulting in the decreased expression of the TLR4 target genes $C O X-2$ and IFN- $\beta$. In broilers, an analysis of global gene expression profiles indicated that the immunomodulatory effects of dietary cinnamaldehyde were related to antigen presentation, humoral immune response and inflammatory disease [25]. In vitro tests showed that chicken spleen lymphocytes treated with cinnamaldehyde ( 25 to $400 \mathrm{ng} / \mathrm{mL}$ ) significantly promoted cell proliferation compared to the control group. The dosages of 1.2 to $5.0 \mu \mathrm{g} / \mathrm{mL}$ of cinnamaldehyde stimulated macrophages to produce more $\mathrm{NO}$, while 0.6 to $2.5 \mu \mathrm{g} / \mathrm{mL}$ inhibited the growth of chicken tumor cells; 10 and $100 \mu \mathrm{g} / \mathrm{mL}$ of cinnamaldehyde lowered the viability of Eimeria tenella [103]. Conversely, in vivo test results showed that dietary supplementation with $14.4 \mathrm{mg} / \mathrm{kg}$ cinnamaldehyde increased mRNA expression of the pro-inflammatory cytokines IL-1 $\beta$, IL-6, IL-15 and IFN- $\gamma$. Cinnamaldehyde supplementation also improved the body weight gain of $E$. acervulina or E. maxima-infected chickens [103]. It should be noted that the dosage of cinnamaldehyde used in this study was very low, and treatment with low concentrations of cinnamaldehyde ( 0.01 to $0.5 \mu \mathrm{g} / \mathrm{mL}$ ) increased NFkB activation in LPS-stimulated human cells in vitro [104]. Further experiments are needed to prove whether cinnamaldehyde has a dose-dependent immunoregulatory effect on birds.

\section{Curcumin}

Curcumin (diferuloylmethane), one of the major components in turmeric, has been extensively researched. Previous studies have shown that curcumin involved in the p38 MAPK signaling pathway in LPS-stimulated RAW 264.7 macrophages [96], produced similar results in dendritic cells [105], and in the colonic tissue of rats with intracolonic injuries [106]. Additionally, Lubbad et al [107] reported that curcumin could suppress inflammation through the reduction of protein levels of TLR4, MyD88, and NFkB. MyD88 is normally recruited after TLR4 activation, and leads to the recruitment of more downstream molecules, as well as the activation of $\mathrm{NFkB}$ [108]. Acute carbon tetrachloride-induced liver damage was also alleviated by reducing the protein production of TNF- $\alpha$ and IL-1 $\beta$ in rats with curcumin treatment [109]. In poultry, the mRNA expression of IL-1 $\beta$, IL-6, IL-12, IL-18 and tumor necrosis factor superfamily 15 were enhanced in chicken 
macrophages treated in vitro with organic extract of turmeric [110]. The mRNA expression of IL-6 in the liver of broilers was increased by aflatoxin $\mathrm{B} 1$ treatment, but alleviated by turmeric powder supplementation [111]. The results of microarray hybridization demonstrated that the gene expression of myeloperoxidase, cluster of differentiation 28 and lactotransferrin are associated with the inflammatory response in broilers [112-114], which was downregulated by treatment with organic extract of turmeric [23]. A series of studies was conducted to evaluate the effect of turmeric oleoresin, which contained $98 \%$ curcuminoids, on the immune response of swine [26,76, $115,116]$. The supplementation significantly reduced serum IL- $1 \beta$ and TNF- $\alpha$ levels in porcine reproductive and respiratory syndrome virus-challenged pigs [26] and counteracted the effects of $E$. coli, as indicated by the markedly altered mRNA expression of IL-1 $\beta$, mucin 2, COX-2 and p38 MAPK in ileal mucosa [76] and serum TNF- $\alpha$ concentration [115]. According to the above reports, in animals, curcumin mainly modulated the p38 MAPK signaling pathway and regulated downstream pro-inflammatory mediators, such as IL-1 $\beta$, IL- 6 , and TNF- $\alpha$.

\section{Thymol}

As the major compound in the essential oils of thyme and oregano, thymol is the isomer of carvacrol; thymol has been shown to possess anti-inflammatory properties; it suppresses the maturation of dendritic cells and activation of $\mathrm{T}$ cell proliferation in vitro [117]. Mature dendritic cells play an important role in the promotion of the immune response. Additionally, thymol inhibited the phosphorylation of NFkB and MAPKs, and lowered the production of IL-6, TNF- $\alpha$, iNOS, and COX-2 in LPS-stimulated mouse mammary epithelial cells [97]. It also reduced the production of $\mathrm{NO}$ and hydrogen peroxide in LPS-stimulated cells [118]. In the jejuna of broilers, supplementation with thyme powder, which contains the essential oils thymol (50.48\%), $\gamma$-terpinene (11.03\%), P-cymene (9.77\%), and carvacrol (4.30\%), significantly decreased transcriptional factor NFkB. Pro-inflammatory cytokines such as IL-6, IFN- $\gamma$, and TNF- $\alpha$ were also downregulated in broilers following treatment with thyme powder [119]. This is consistent with previously mentioned results, suggesting that the anti-inflammatory effects of thyme make it suitable for application in animal production.

\section{CONCLUSION}

As it is inevitable for animals to be faced with environmental stressors like heat, disease and microbial toxins, the defense system of the host plays a vital role in maintaining health as well as growth performance and production. According to the above reports, the immune response improved when animal diets were supplemented with cinnamon, oregano, turmeric or thyme products. The stress response was alleviated since the NFKB and MAPKs signaling pathways were suppressed, and the expression of anti-inflammatory cytokines was increased. As a result, the blood levels of non-specific immune cells such as heterophils (neutrophils) were lowered, and lymphocyte and antibody production were promoted to defend against invading pathogens. Essentially, the less energy expended by chickens and pigs on the non-specific immune system, the more energy that is available for growth and production. Conclusively, phytochemicals did modulate NFKB and/or MAPKs signaling pathways in chickens and pigs, but the detailed mechanisms, including expression of upstream molecules involving NFkB and MAPKs signaling as well as the relationship between antioxidant and anti-inflammation, are still under investigation.

\section{CONFLICT OF INTEREST}

We certify that there is no conflict of interest with any financial organization regarding the material discussed in the manuscript.

\section{ACKNOWLEDGMENTS}

The authors would like to express the sincere gratitude to the Ministry of Science and Technology (MOST 106-2313-B-005048) and the iEGG and Animal Biotechnology Center for financially supporting the study to Prof. Tzu-Tai Lee.

\section{REFERENCES}

1. Lee MT, Lin WC, Yu B, Lee TT. Antioxidant capacity of phytochemicals and their potential effects on oxidative status in animals - A review. Asian-Australas J Anim Sci 2017;30: 299-308.

2. Blackwell TS, Blackwell TR, Holden EP, Christman BW, Christman JW. In vivo antioxidant treatment suppresses nuclear factor-kappa B activation and neutrophilic lung inflammation. J Immunol 1996;157:1630-7.

3. Cuzzocrea S, Riley DP, Caputi AP, Salvemini D. Antioxidant therapy: a new pharmacological approach in shock, inflammation, and ischemia/reperfusion injury. Pharmacol Rev 2001; 53:135-59.

4. Tarabova L, Makova Z, Piesova E, Szaboova R, Faixova Z. Intestinal mucus layer and mucins (a review). Folia Vet 2016; 60:21-5.

5. Arce C, Ramı'rez-Boo M, Lucena C, Garrido JJ. Innate immune activation of swine intestinal epithelial cell lines (IPEC-J2 and IPI-2I) in response to LPS from Salmonella typhimurium. Comp Immunol Microbiol Infect Dis 2010;33:161-74.

6. Yunus AW, Razzazi-Fazeli E, Bohm J. Aflatoxin B1 in Affecting broiler's performance, immunity, and gastrointestinal tract: a review of history and contemporary issues. Toxins 2011;3: 
566-90.

7. Miles DM, Branton SL, Lott BD. Atmospheric ammonia is detrimental to the performance of modern commercial broilers. Poult Sci 2004;83:1650-4.

8. Drummond JG, Curtis SE, Simon J, Norton HW. Effect of aerial ammonia on growth and health of young pigs. J Anim Sci 1980;50:1085-9.

9. Quinteiro-Filho WM, Gomes AVS, Pinheiro ML, et al. Heat stress impairs performance and induces intestinal inflammation in broiler chickens infected with Salmonella enteritidis. Avian Pathol 2012;415:421-7.

10. Williams RB. A compartmentalised model for the estimation of the cost of coccidiosis to the world's chicken production industry. Int J Parasitol 1999;29:1209-29.

11. McLamb BL, Gibson AJ, Overman EL, Stahl C, Moeser AJ. Early weaning stress in pigs impairs innate mucosal immune responses to enterotoxigenic $E$. coli challenge and exacerbates intestinal injury and clinical disease. PLoS One 2013;8:e59838.

12.Lin WC, Lee MT, Lo CT, Chang SC, Lee TT. Effects of dietary supplementation of Trichoderma pseudokoningii fermented enzyme powder on growth performance, intestinal morphology, microflora and serum antioxidantive status in broiler chickens. Ital J Anim Sci 2018;17:153-64.

13. Lin WC, Lee MT, Chang YL, et al. Effects of mulberry leaves on production performance and the potential modulation of antioxidative status in laying hens. Poult Sci 2017;96:1191-203.

14. Teng PY, Chung CH, Chao YP, et al. Effects of Bacillus amyloliquefaciens and Saccharomyces cerevisiae as directed-fed microbials on performance, intestinal microflora, and intestinal morphology in broiler chickens. J Poult Sci 2017;54:134-41.

15. Lin MJ, Chang SC, Jea YS, et al. In vitro antioxidant capability and performance assessment of White Roman goose supplemented with dried Toona sinensis. J Appl Anim Res 2016;44:359402.

16.Lai LP, Lee MT, Chen J, Yu B, Lee TT. Effects of co-fermented Pleurotus eryngii stalk residues and soybean hulls by Aureobasidium pullulans on performance and intestinal morphology in broiler chickens. Poult Sci 2015;94:2959-69.

17.Lin MJ, Chang SC, Jea YS, Chen WS, Lee TT. Effects of dietary garlic scape meal on the growth and meat characteristics of geese. Br Poult Sci 2015;56:716-22.

18. Jang IS, Ko YH, Yang HY, et al. Influence of essential oil components on growth performance and the functional activity of the pancreas and small intestine in broiler chickens. AsianAustralas J Anim Sci 2004;17:394-400.

19. Jamroz D, Wiliczkiewicz A, Wertelecki T, Orda J, Skorupińska J. Use of active substances of plant origin in chicken diets based on maize and locally grown cereals. Br Poult Sci 2005;46:48593.

20.Li P, Piao X, Ru Y, et al. Effects of adding essential oil to the diet of weaned pigs on performance, nutrient utilization, immune response and intestinal health. Asian-Australas J Anim Sci
2012;25:1617-26.

21. Fascina VB, Sartori JR, Gonzales E, et al. Phytogenic additives and organic acids in broiler chicken diets. R Bras Zootec 2012; 41:2189-97.

22. Kim DK, Lillehoj HS, Lee SH, et al. Immune effects of dietary anethole on Eimeria acervulina infection. Poult Sci 2013;92: 2625-34.

23. Kim DK, Lillehoj HS, Lee SH, et al. Dietary Curcuma longa enhances resistance against Eimeria maxima and Eimeria tenella infections in chickens. Poult Sci 2013;92:2635-43.

24.Alp M, Midilli M, Kocabağlı N, et al. The effects of dietary oregano essential oil on live performance, carcass yield, serum immunoglobulin G level, and oocyst count in broilers. J Appl Poult Res 2012;21:630-6.

25.Lillehoj HS, Kim DK, Bravo DM, Lee SH. Effects of dietary plant-derived phytonutrients on the genome-wide profiles and coccidiosis resistance in the broiler chickens. BMC Proc 2011; 5(Suppl 4):S34.

26. Liu Y, Che TM, Song M, et al. Dietary plant extracts improve immune responses and growth efficiency of pigs experimentally infected with porcine reproductive and respiratory syndrome virus. J Anim Sci 2013;91:5668-79.

27.Bakkali F, Averbeck S, Averbeck D, Idaomar M. Biological effects of essential oils - A review. Food Chem Toxicol 2008; 46:446-75.

28. Fang SC, Hsu CL, Yen GC. Anti-inflammatory effects of phenolic compounds isolated from the fruits of Artocarpus heterophyllus. J Agric Food Chem 2008;56:4463-8.

29. Siani AC, Souza MC, Henriques MG, Ramos MF. Anti-inflammatory activity of essential oils from Syzygium cumini and Psidium guajava. Pharm Biol 2013;51:881-7.

30.Lin SJ, Chen CS, Ho CC, et al. In vitro anti-microbial and in vivo cytokines modulation effects of different prepared Chinese herbal medicines. Food Chem Toxicol 2006;44:2078-85.

31.Lin SS, Lu TM, Chao PC, et al. In vivo cytokine modulatory effects of cinnamaldehyde, the major constituent of leaf essential oil from Cinnamomum osmophloeum Kaneh. Phytother Res 2011;25:1511-8.

32. Lee TT, Chen CL, Shieh ZH, Lin JC, Yu B. Study on antioxidant activity of Echinacea purpurea L. extracts and its impact on cell viability. Afr J Biotechnol 2009;8:5097-105.

33.Lee TT, Chen CL, Wang CC, Yu B. Growth performance and antioxidant capacity of broilers supplemented with Echinacea purpurea L. in the diet. J Appl Poult Res 2012;21:484-91.

34.Lee TT, Ciou JY, Chen CL, Yu B. Effect of Echinacea purpurea L. on oxidative status and meat quality in Arbor Acres broilers. J Sci Food Agric 2013;93:166-72.

35.Landy N, Ghalamkari Gh, Toghyani M, Moattar F. The effects of Echinacea purpurea L. (purple coneflower) as an antibiotic growth promoter substitution on performance, carcass characteristics and humoral immune response in broiler chickens. J Med Plants Res 2011;5:2332-8. 
36. Böhmer BM, Salisch H, Paulicks BR, Roth FX. Echinacea purpurea as a potential immunostimulatory feed additive in laying hens and fattening pigs by intermittent application. Livest Sci 2009;122:81-5.

37. Rahimi S, Zadeh ZT, Torshizi MAK, Omidbaigi R, Rokni H. Effect of the three herbal extracts on growth performance, immune system, blood factors and intestinal selected bacterial population in broiler chickens. J Agric Sci Tech 2011;13:52739.

38. Maass N, Bauer J, Paulicks BR, Böhmer BM, Roth-Maier DA. Efficiency of Echinacea purpurea on performance and immune status in pigs. J Anim Physiol Anim Nutr 2005;89:244-52.

39. Lagouri V, Blekas G, Tsimidou M, Kokkini S, Boskou D. Composition and antioxidant activity of essential oils from Oregano plants grown wild in Greece. Z Lebensm Unters Forsch 1993; 197:20-3.

40.Mohiti-Asli M, Ghanaatparast-Rashti M. Comparison of the effect of two phytogenic compounds on growth performance and immune response of broilers. J Appl Anim Res 2017;45: 603-8.

41. Galal AAAE, El-Araby IE, Hassanin O, El-Said Omar A. Positive impact of oregano essential oil on growth performance, humoral immune responses and chicken interferon alpha signalling pathway in broilers. Adv Anim Vet Sci 2016;4:57-65.

42. Gross WB, Siegel HS. Evaluation of the heterophil/lymphocyte ratio as a measure of stress in chickens. Avian Dis 1983;27:9729.

43. Ariza-Nieto C, Bandrick M, Baidoo SK, et al. Effect of dietary supplementation of oregano essential oils to sows on colostrum and milk composition, growth pattern and immune status of suckling pigs. J Anim Sci 2011;89:1079-89.

44. Hashemipour H, Kermanshahi H, Golian A, Veldkamp T. Effect of thymol and carvacrol feed supplementation on performance, antioxidant enzyme activities, fatty acid composition, digestive enzyme activities, and immune response in broiler chickens. Poult Sci 2013;92:2059-69.

45. Karimi A, Yan F, Coto C, et al. Effects of level and source of oregano leaf in starter diets for broiler chicks. J Appl Poult Res 2010;19:137-45.

46. Wang R, Wang R, Yang B. Extraction of essential oils from five cinnamon leaves and identification of their volatile compound compositions. Innov Food Sci Emerg Technol 2009;10:289-92.

47.Schmidt E, Jirovetz L, Buchbauer G, et al. Composition and antioxidant Activities of the essential oil of cinnamon (Cinnamomum zeylanicum Blume) leaves from Sri Lanka. J Essent Oil Bear Pl 2006;9:170-82.

48. Shirzadegan K. Reactions of modern broiler chickens to administration of cinnamon powder in the diet. Iran J Appl Anim Sci 2014;4:367-71.

49.Sang-Oh P, Chae-Min R, Byung-Sung P, Jong H. The meat quality and growth performance in broiler chickens fed diet with cinnamon powder. J Environ Biol 2013;34:127-33.
50.Al-Kassie GAM. The effect of thyme and cinnamon on the microbial balance in gastro intestinal tract on broiler chicks. Int J Poult Sci 2010;9:495-8.

51.Najafi S, Taherpour K. Effects of dietary ginger (Zingiber Ofjicinale), cinnamon (Cinnamomum), synbiotic and antibiotic supplementation on performance of broilers. J Anim Sci Adv 2014;4:658-67.

52. Al-Kassie GAM. Influence of two plant extracts derived from thyme and cinnamon on broiler performance. Pakistan Vet J 2009;29:169-73.

53. Sadeghi GH, Karimi A, Padidar Jahromi SH, Azizi T, Daneshmand A. Effects of cinnamon, thyme and turmeric infusions on the performance and immune response in of 1- to 21-dayold male broilers. Rev Bras Cienc Avic 2012;14:15-20.

54.Li S, Yuan W, Deng G, et al. Chemical composition and product quality control of turmeric (Curcuma longa L.). Pharm Crop 2011;2:28-54.

55. Emadi M, Kermanshahi H. Effect of turmeric rhizome powder on immunity responses of broiler chickens. J Anim Vet Adv 2007;6:833-6.

56. Akhavan-Salamat H, Ghasemi HA. Alleviation of chronic heat stress in broilers by dietary supplementation of betaine and turmeric rhizome powder: dynamics of performance, leukocyte profile, humoral immunity, and antioxidant status. Trop Anim Health Prod 2016;48:181-8.

57. Nouzarian R, Tabeidian SA, Toghyani M, Ghalamkari G, Toghyani $M$. Effect of turmeric powder on performance, carcass traits, humoral immune responses, and serum metabolites in broiler chickens. J Anim Feed Sci 2011;20:389-400.

58. Hudaib M, Speroni E, Pietra AMD, Cavrini V. GC/MS evaluation of thyme (Thymus vulgaris L.) oil composition and variations during the vegetative cycle. J Pharm Biomed Anal 2002;29:691-700.

59. Senatore F. Influence of Harvesting Time on yield and composition of the essential oil of a thyme (Thymus pulegioides L.) growing wild in Campania (Southern Italy). J Agric Food Chem 1996;44:1327-32.

60. Khaksar V, Golian A, Kermanshahi H. Immune response and ileal microflora in broilers fed wheat-based diet with or without enzyme Endofeed W and supplementation of thyme essential oil or probiotic PrimaLac. Afr J Biotechnol 2012;11:14716-23.

61.Jahanian R, Rasouli E. Dietary chromium methionine supplementation could alleviate immunosuppressive effects of heat stress in broiler chicks. J Anim Sci 2015;93:3355-63.

62. Brisbin JT, Gong J, Sharif S. Interactions between commensal bacteria and the gut-associated immune system of the chicken. Anim Health Res Rev 2008;9:101-10.

63. Burkholder KM, Thompson KL, Einstein ME, Applegate TJ, Patterson JA. Influence of stressors on normal intestinal microbiota, intestinal morphology, and susceptibility to Salmonella enteritidis colonization in broilers. Poult Sci 2008;87:1734-41. 64. Najafi P, Torki M. Performance, blood metabolites and im- 
munocompetence of broiler chicks fed diets included essential oils of medicinal herbs. J Anim Vet Adv 2010;9:1164-8.

65. Akira S, Uematsu S, Takeuchi O. Pathogen recognition and innate immunity. Cell 2006;124:783-801.

66. Medzhitov R, Janeway Jr CA. Innate immunity: impact on the adaptive immune response. Curr Opin Immunol 1997;9:4-9.

67.Li H, Zhang L, Chen L, et al. Lactobacillus acidophilus alleviates the inflammatory response to enterotoxigenic Escherichia coli K88 via inhibition of the NF- $\mathrm{kB}$ and p38 mitogen-activated protein kinase signaling pathways in piglets. BMC Microbiol 2016;16:273.

68. MacKinnon KM, He H, Nerren JR, et al. Expression profile of toll-like receptors within the gastrointestinal tract of 2-day-old Salmonella enteriditis-infected broiler chickens. Vet Microbiol 2009;137:313-9.

69. Ramasamy KT, Verma P, Reddy MR. Toll-like receptors gene expression in the gastrointestinal tract of Salmonella serovar Pullorum-infected broiler chicken. Appl Biochem Biotechnol 2014;173:356-64.

70.Zhu J, Mohan C. Toll-like receptor signaling pathways--therapeutic opportunities. Mediators Inflamm 2010;2010:781235.

71.Li Q, Verma IM. NF-kappaB regulation in the immune system. Nat Rev Immunol 2002;2:725-34.

72. Byeon SE, Yi YS, Oh J, et al. The role of Src kinase in macrophage-mediated inflammatory responses. Mediators Inflamm 2012;2012:Article ID 512926.

73. Yu T, Yi YS, Yang Y, et al. The pivotal role of TBK1 in inflammatory responses mediated by macrophages. Mediators Inflamm 2012;2012:Article ID 979105.

74. Raingeaud J, Gupta S, Rogers JS, et al. Pro-inflammatory cytokines and environmental stress cause p38 mitogen-activated protein kinase activation by dual phosphorylation on tyrosine and threonine. J Biol Chem 1995;270:7420-6.

75. Genovese KJ, He H, Lowry VK, Kogut MH. Comparison of MAP and tyrosine kinase signaling in heterophils from commercial and wild-type turkeys. Dev Comp Immunol 2007;31: 927-33.

76.Liu Y, Song M, Che TM, et al. Dietary plant extracts modulate gene expression profiles in ileal mucosa of weaned pigs after an Escherichia coli infection. J Anim Sci 2014;92:2050-62.

77. Coux O, Tanaka K, Goldberg AL. Structure and functions of the $20 \mathrm{~S}$ and $26 \mathrm{~S}$ proteasomes. Annu Rev Biochem 1996;65:80147.

78. Taofiq O, Martins A, Barreiro MF, Ferreira ICFR. Anti-inflammatory potential of mushroom extracts and isolated metabolites. Trends Food Sci Technol 2016;50:193-210.

79. Ravi R, Bedi GC, Engstrom LW, et al. Regulation of death receptor expression and TRAIL/Apo2L-induced apoptosis by NF-kappaB. Nat Cell Biol 2001;3:409-16.

80. Gessner DK, Fiesel A, Most E, et al. Supplementation of a grape seed and grape marc meal extract decreases activities of the oxidative stress-responsive transcription factors NF- $\mathrm{kB}$ and
Nrf2 in the duodenal mucosa of pigs. Acta Vet Scand 2013; 55:18.

81.Zhao FQ, Zhang ZW, Wang C, et al. The role of heat shock proteins in inflammatory injury induced by cold stress in chicken hearts. Cell Stress Chaperones 2013;18:773-83.

82. Klasing KC, Johnstone BJ. Monokines in growth and development. Poult Sci 1991;70:1781-9.

83. Johnson RW. Inhibition of growth by pro-inflammatory cytokines: an integrated view. J Anim Sci 1997;75:1244-55.

84. Koch AE, Kunkel SL, Harlow LA, et al. Enhanced production of monocyte chemoattractant protein-1 in rheumatoid arthritis. J Clin Invest 1992;90:772-9.

85. Ghareeb K, Awad WA, Soodoi C, et al. Effects of feed contaminant deoxynivalenol on plasma cytokines and mRNA expression of immune genes in the intestine of broiler chickens. PLoS One 2013;8:e71492.

86. Guzik TJ, Korbut R, Adamek-Guzik T. Nitric oxide and superoxide in inflammation and immune regulation. J Physiol Pharmacol 2003;54:469-87.

87. Harizi H, Gualde N. Pivotal role of PGE2 and IL-10 in the cross-regulation of dendritic cell-derived inflammatory mediators. Cell Mol Immunol 2006;3:271-7.

88. Hseu YC, Wu FY, Wu JJ, et al. Anti-inflammatory potential of Antrodia Camphorata through inhibition of iNOS, COX-2 and cytokines via the NF-kappaB pathway. Int Immunopharmacol 2005;5:1914-25.

89. Dy M, Schneider E. Histamine-cytokine connection in immunity and hematopoiesis. Cytokine Growth Factor Rev 2004; 15:393-410.

90.Besedovsky HO, del Rey A, Klusman I, et al. Cytokines as modulators of the hypothalamus-pituitary-adrenal axis. J Steroid Biochem Mol Biol 1991;40:613-8.

91.Shini S, Shini A, Kaiser P. Cytokine and chemokine gene expression profiles in heterophils from chickens treated with corticosterone. Stress 2010;13:185-94.

92.Shini S, Huff GR, Shini A, Kaiser P. Understanding stressinduced immunosuppression: exploration of cytokine and chemokine gene profiles in chicken peripheral leukocytes. Poult Sci 2010;89:841-51.

93. Kabir SML. Avian colibacillosis and salmonellosis: a closer look at epidemiology, pathogenesis, diagnosis, control and public health concerns. Int J Environ Res Public Health 2010; 7:89-114.

94.Jin Y, Hu Y, Han D, Wang M. Chronic Heat stress weakened the innate immunity and increased the virulence of highly pathogenic avian influenza virus $\mathrm{H} 5 \mathrm{~N}$ in mice. J Biomed Biotechnol 2011;2011:367846.

95. Youn HS, Lee JK, Choi YJ, et al. Cinnamaldehyde suppresses toll-like receptor 4 activation mediated through the inhibition of receptor oligomerization. Biochem Pharmacol 2008;75: 494-502.

96. Guimarães MR, Leite FRM, Spolidorio LC, Kirkwood KL, Rossa 
C. Curcumin abrogates LPS-induced proinflammatory cytokines in RAW 264.7 macrophages. Evidence for novel mechanisms involving SOCS-1, -3 and p38 MAPK. Arch Oral Biol 2013;58:1309-17.

97.Liang D, Li F, Fu Y, et al. Thymol inhibits LPS-stimulated inflammatory response via down-regulation of NF- $\mathrm{kB}$ and MAPK signaling pathways in mouse mammary epithelial cells. Inflammation 2014;37:214-22.

98. Lima Mda S, Quintans-Júnior LJ, de Santana WA, et al. Antiinflammatory effects of carvacrol: evidence for a key role of interleukin-10. Eur J Pharmacol 2013;699:112-7.

99. Cho S, Choi Y, Park S, Park T. Carvacrol prevents diet-induced obesity by modulating gene expressions involved in adipogenesis and inflammation in mice fed with high-fat diet. J Nutr Biochem 2012;23:192-201.

100. Zou Y, Xiang Q, Wang J, Peng J, Wei H. Oregano essential oil improves intestinal morphology and expression of tight junction proteins associated with modulation of selected intestinal bacteria and immune status in a pig model. Biomed Res Int 2016;2016:Article ID5436738.

101. Lu H, Adedokun SA, Adeola L, Ajuwon KM. Anti-inflammatory effects of non-antibiotic alternatives in coccidia challenged broiler chickens. J Poult Sci 2014;51:14-21.

102. Pannee C, Chandhanee I, Wacharee L. Antiinflammatory effects of essential oil from the leaves of Cinnamomum cassia and cinnamaldehyde on lipopolysaccharide-stimulated J774A.1 cells. J Adv Pharm Technol Res 2014;5:164-70.

103. Lee SH, Lillehoj HS, Jang SI. Cinnamaldehyde enhances in vitro parameters of immunity and reduces in vivo infection against avian coccidiosis. Br J Nutr 2011;106:862-9.

104. Roth-Walter F, Moskovskich A, Gomez-Casado C, et al. Immune suppressive effect of cinnamaldehyde due to inhibition of proliferation and induction of apoptosis in immune cells: implications in cancer. PLoS One 2014;9:e108402.

105. Kim GY, Kim KH, Lee SH, et al. Curcumin inhibits immunostimulatory function of dendritic cells: MAPKs and translocation of NF-kappa B as potential targets. J Immunol 2005; 174:8116-24.

106. Camacho-Barquero L, Villegas I, Sánchez-Calvo JM, et al. Curcumin, a Curcuma longa constituent, acts on MAPK p38 pathway modulating COX-2 and iNOS expression in chronic experimental colitis. Int Immunopharmacol 2007;7:333-42.

107. Lubbad A, Oriowo MA, Khan I. Curcumin attenuates inflammation through inhibition of TLR-4 receptor in experimental colitis. Mol Cell Biochem 2009;322:127-35.
108. Karnati HK, Pasupuleti SR, Kandi R, et al. TLR-4 signalling pathway: MyD88 independent pathway up-regulation in chicken breeds upon LPS treatment. Vet Res Commun 2015; 39:73-8.

109. Reyes-Gordillo K, Segovia J, Shibayama M, et al. Curcumin protects against acute liver damage in the rat by inhibiting NFkappaB, proinflammatory cytokines production and oxidative stress. Biochim Biophys Acta 2007;1770:989-96.

110. Lee SH, Lillehoj HS, Hong YH, et al. In vitro effects of plant and mushroom extracts on immunological function of chicken lymphocytes and macrophages. Br Poult Sci 2010;51:213-21.

111. Yarru LP, Settivari RS, Gowda NK, et al. Effects of turmeric (Curcuma longa) on the expression of hepatic genes associated with biotransformation, antioxidant, and immune systems in broiler chicks fed aflatoxin. Poult Sci 2009;88:2620-7.

112. Che Z, Liu Y, Wang H, et al. The protective effects of different mycotoxin adsorbents against blood and liver pathological changes induced by mold-contaminated feed in broilers. AsianAustralas J Anim Sci 2011;24:250-7.

113. Malek M, Hasenstein JR, Lamont SJ. Analysis of chicken TLR4, CD28, MIF, MD-2, and LITAF genes in a Salmonella enteritidis resource population. Poult Sci 2004;83:544-9.

114. Gilbert ER, Cox CM, Williams PM, et al. Eimeria species and genetic background influence the serum protein profile of broilers with coccidiosis. PLoS One 2011;6:e14636.

115. Liu Y, Song M, Che TM, et al. Dietary plant extracts alleviate diarrhea and alter immune responses of weaned pigs experimentally infected with a pathogenic Escherichia coli. J Anim Sci 2013;91:5294-306.

116. Liu Y, Song M, Che TM, et al. Effects of capsicum oleoresin, garlic botanical, and turmeric oleoresin on gene expression profile of ileal mucosa in weaned pigs. J Anim Sci 2014;92: 3426-40.

117. Amirghofran Z, Ahmadi H, Karimi MH, et al. In vitro inhibitory effects of thymol and carvacrol on dendritic cell activation and function. Pharm Biol 2016;54:1125-32.

118. Kavoosi G, Teixeira da Silva JA, Saharkhiz, MJ. Inhibitory effects of Zataria multiflora essential oil and its main components on nitric othyxide and hydrogen peroxide production in lipopolysaccharide-stimulated macrophages. J Pharm Pharmacol 2012;64:1491-500.

119. Hassan FAM, Awad A. Impact of thyme powder (Thymus vulgaris L.) supplementation on gene expression profiles of cytokines and economic efficiency of broiler diets. Environ Sci Pollut Res Int 2017;24:15816-26. 